\title{
The pattern of decline in bacillary index after 2 years of WHO recommended multiple drug therapy: the AMFES cohort
}

\author{
ASSEFA AMENU*, PAUL SAUNDERSON*, \\ KETSELA DESTA* \& PETER BYASS** \\ *ALERT, PO Box 165, Addis Ababa, Ethiopia \\ **School of Community Health Science, Nottingham University, \\ Nottingham, UK and Department of Public Health and Clinical \\ Medicine, Umeå University, Umeå, Sweden
}

Accepted for publication 16 June 2000

\begin{abstract}
Summary With effective antibiotic treatment, the bacillary index (BI) in multibacillary leprosy patients declines over a number of years. This can be quantified as a rate of decline in log-units per year or as the time until smear negativity is reached. In the AMFES cohort 220 cases had data on the changes in their BI over time, while 170 cases are documented until smear negativity. The average BI at the start was 3.3 (SD 1.5 ; range $0.3-5.5$ ) and the mean rate of decline was 0.85 units per year (median 0.7 units per year); in the first 2 years after diagnosis, the mean rate of decline was 1.15 units per year. The rate of decline was not related to any clinical features of the disease except delay in diagnosis: patients presenting for treatment early had a significantly faster rate of clearing the bacilli (adjusted relative risk 2.3 ; 95\% CI 1.0 $5 \cdot 1)$. Fifty-eight percent of cases took longer than 3 years to reach smear negativity, but this time interval is largely determined by the initial BI and classification, making it a less useful indicator of bacterial clearance. More severe impairment at the start of treatment was associated with a faster return to smear negativity, for which no obvious explanation can be given. Reversal reactions, which occurred in $25 \%$ of the cases reviewed, are not associated with a more rapid clearance of bacilli.
\end{abstract}

\section{Introduction}

Multiple drug therapy (MDT) has been a very successful development in the treatment of leprosy, with rapid killing of the bacilli. After 2 years of treatment with the multibacillary regimen, relapses are as low as $0.77 \%$. $^{1}$ This has given WHO the grounds to reduce the recommended length of treatment from 24 to 12 months, ${ }^{2}$ although the wisdom of this change is questioned by some. ${ }^{3-5}$

One component of the evaluation of treatment regimens for leprosy is the examination of

Correspondence to: P. Saunderson, ALM, 1 ALM Way, Greenville SC 29601, USA (e-mail: prsaunderson@ hotmail.com) 
serial slit skin smears and the recording of changes in the bacillary index (BI), commonly reported as the average rate of decline in log-units per year, ${ }^{6,7}$ or as the number of years taken to reach smear negativity. 8,9

Reported average rates of decrease in BI range from 0.57 to 1.01 log-units/year, ${ }^{6,7}$ but factors associated with different rates of decline have not been elucidated. One study in Paris used the time to smear negativity to examine possible risk factors affecting the removal of bacilli. The study was largely concerned with treatment results and the information regarding decline in $\mathrm{BI}$ is not given in detail. Forty-four MB cases (26 BB/BL and $18 \mathrm{LL}$ cases) were followed, of whom 19 (43\%) had reversal reactions and 18 (41\%) had ENL reactions. The time to smear negativity was not significantly different for relapse cases (12) and previously untreated cases (32). The time to negativity was, however, said to be significantly shorter in those with a lower BI at the start $(P<001)$ and in those who had reversal reactions $(P<0.001)$. It was longer in those who had ENL reactions $(P<0.01)$. No multivariate analysis was done. ${ }^{9}$

The AMFES cohort is a large group of Ethiopian patients followed prospectively for up to 10 years, which has allowed the pattern of decline in BI to be closely examined and possible risk factors to be searched for. Such risk factors include the clinical features of the disease at diagnosis, factors that may modify the body's response to the disease and the variations in the clinical course of the disease after diagnosis.

Classification is associated with many of the initial clinical features of the disease, including the BI and number of skin lesions. Reversal reactions may occur before or after diagnosis and may be associated with nerve damage; they are caused by an upgrading of the cell-mediated immune response to leprosy bacilli in the tissues and could therefore be associated with an increased rate of clearance of bacilli. Impairment is assumed to be the result of excessive immunological activity focused on bacilli in and around the nerves, so may be expected to be associated with increased clearance of bacilli. A delay between the onset of symptoms and diagnosis is known to be associated with greater impairment at diagnosis ${ }^{10}$ and could therefore be associated with increased clearance of bacteria. On the other hand, the down-grading of the immune response that occurs in the absence of treatment could lead to slower clearance of bacilli in those with a greater delay in starting treatment.

\section{Materials and methods}

In all, 660 patients were enrolled in the ALERT MDT Field Evaluation Study (AMFES) between March 1988 and March 1993. Ten patients were excluded, either because the diagnosis was changed or the enrolment procedures were incorrectly followed. A further 56 patients who had relapsed after dapsone monotherapy are not included in this review. Of 594 new cases, 300 were multibacillary cases and 220 of these cases, who have a series of at least three smears, are reviewed. The pattern of decline in BI is related to the clinical features and progress of each case. As only three BT cases are included in the study, they are grouped with the BL cases for analysis.

During and after MDT treatment, skin smears were taken every 6 months. Smears were taken from four sites - the two ear lobes, an elbow and a knee or from an active lesion, according to the protocol then in operation at ALERT. Smears were collected and transported for reading at the ALERT hospital by experienced laboratory technicians. The laboratory has a regular quality control service both for the technicians and the field 
workers. In addition to basic patient characteristics (age, sex), the progress of their disease was characterized (Ridley-Jopling class, eye-hand-foot (EHF) impairment scores at different stages, delay on initial diagnosis, reactions and steroid therapy). Reversal reactions were defined as the occurrence of signs of inflammation in known leprosy skin lesions, while ENL reactions were defined as the presence of typical ENL skin lesions, away from the known leprosy skin lesions.

In addition, HIV testing was carried out on all but 14 of the 220 patients. HIV testing used a combination of two different ELISA systems and a rapid assay. Samples were first tested using Vironistika ELISA kit (Organon Teknika, Boxtel, Holland) and reactive samples were re-tested by Wellcozyme ELISA kit (Murex Diagnostics, Dartford, UK). A third, rapid test (HIV-SPOT, Genelabs Diagnostics, Singapore) was used for those sera which gave discrepant results in the first two ELISAs. All tests are sensitive for HIV-1 and HIV-2.

Data were managed using dBase and Epi-Info, whilst Egret was used for multivariate regression analysis.

\section{Results}

A total of 220 cases with an initial positive skin smear and more than one follow-up smear were included, and the rates of decline of the BI in units per year were calculated. The average $\mathrm{BI}$ at the start was 3.3 (SD 1.5; range 0.3-5.5). The mean rate of decline was 0.85 units per year, with a median of 0.7 units per year. In the first 2 years after diagnosis, looked at separately, the mean rate of decline was $1 \cdot 15$ units per year.

The patients were divided into two groups, those whose BI declined quickly at over 1 unit per year $(n=62)$ and those whose BI declined slowly at less than 1 unit per year $(n=158)$. Table 1 shows the factors associated with a slow decline in BI. Delayed diagnosis and a higher impairment score at the end of treatment were significantly associated with a slow decline in BI on a univariate basis, with only the former emerging as a significant factor on a multivariate basis. Since it could be argued that this might simply reflect a fast pre-diagnostic decline, the multivariate regression was repeated without this factor; this did not significantly change the other factors. The use of steroids is employed here as a marker for new episodes of neuritis, which together with reversal reactions and ENL reactions, may reflect increased immunological activity, but there is no evidence here to suggest that this promotes the clearance of bacilli from the body.

An alternative way to look at the decline in $\mathrm{BI}$ is to examine the time until the smears became negative. A total of 172 cases have smear results until negativity. Of these, 100 took longer than 3 years and 72 took less than 3 years to become negative. Table 2 examines the factors associated with a slow return to negativity. Three factors emerge as significant both in univariate and multivariate analyses: LL patients, a high initial BI and less impairment at diagnosis.

\section{Discussion}

The rate of decline of the BI in multibacillary leprosy patients treated with MDT is similar in most reported series and the rate found in this cohort is in the centre of the reported range of $0.57-1.01 \mathrm{log}$-units per year. 
Table 1. Univariate and multiple logistic regression analysis of risk factors associated with a slow decline in BI in 220 Ethiopian leprosy patients

\begin{tabular}{|c|c|c|c|c|c|c|}
\hline Risk factor & Category & $\begin{array}{l}\text { Number } \\
\text { of cases }\end{array}$ & $\begin{array}{l}\text { Univariate } \\
\text { relative risk }\end{array}$ & $95 \%$ CI & $\begin{array}{l}\text { Adjusted } \\
\text { relative risk }\end{array}$ & $95 \% \mathrm{CI}$ \\
\hline Age group & $\begin{array}{l}<20 \\
20-49 \\
50+\end{array}$ & $\begin{array}{r}58 \\
128 \\
34\end{array}$ & $\begin{array}{l}1 \cdot 0 \\
1 \cdot 4 \\
1 \cdot 2\end{array}$ & $\begin{array}{l}-\overline{0} \\
0 \cdot 71-2 \cdot 8 \\
0 \cdot 47-2 \cdot 9\end{array}$ & $\begin{array}{l}1 \cdot 0 \\
1 \cdot 3 \\
1 \cdot 4\end{array}$ & $\begin{array}{l}- \\
0 \cdot 61-2 \cdot 8 \\
0 \cdot 44-4 \cdot 1\end{array}$ \\
\hline Sex & $\begin{array}{l}\text { Male } \\
\text { Female }\end{array}$ & $\begin{array}{r}148 \\
72\end{array}$ & $\begin{array}{l}1.0 \\
1.6\end{array}$ & $\overline{0} \cdot 82-3 \cdot 0$ & $\begin{array}{l}1.0 \\
1.6\end{array}$ & $\overline{0}-76-3 \cdot 2$ \\
\hline $\mathrm{RJ}$ class & $\begin{array}{l}\text { BL } \\
\text { LL }\end{array}$ & $\begin{array}{r}151 \\
69\end{array}$ & $\begin{array}{l}1 \cdot 0 \\
0 \cdot 85\end{array}$ & $\overline{0.46-1.6}$ & $\begin{array}{l}1 \cdot 0 \\
0.90\end{array}$ & $\overline{0}-39-2 \cdot 1$ \\
\hline Initial BI & $\begin{array}{l}<4 \\
4,5 \text { or } 6\end{array}$ & $\begin{array}{r}63 \\
157\end{array}$ & $\begin{array}{l}1 \cdot 0 \\
0 \cdot 61\end{array}$ & $\overline{0} \cdot 34-1 \cdot 1$ & $\begin{array}{l}1 \cdot 0 \\
0 \cdot 80\end{array}$ & $\overline{0} \cdot 36-1 \cdot 8$ \\
\hline Delay before diagnosis & $\begin{array}{l}\text { up to } 2 \text { years } \\
3 \text { or more years }\end{array}$ & $\begin{array}{r}144 \\
76\end{array}$ & $\begin{array}{l}1 \cdot 0 \\
2 \cdot 5^{* *}\end{array}$ & $\overline{1 \cdot 3-5 \cdot 0}$ & $\begin{array}{l}1 \cdot 0 \\
2 \cdot 3^{* *}\end{array}$ & $-\overline{1 \cdot 0-5 \cdot 1}$ \\
\hline EHF at diagnosis & $\begin{array}{l}<3 \\
3 \text { or more }\end{array}$ & $\begin{array}{r}160 \\
60\end{array}$ & $\begin{array}{l}1.0 \\
1.6\end{array}$ & $\overline{0} \cdot 8-3 \cdot 2$ & $\begin{array}{l}1 \cdot 0 \\
0 \cdot 71\end{array}$ & $\overline{0} \cdot 26-1 \cdot 9$ \\
\hline EHF at RFT & $\begin{array}{l}<3 \\
3 \text { or more }\end{array}$ & $\begin{array}{r}175 \\
45\end{array}$ & $\begin{array}{l}1 \cdot 0 \\
2 \cdot 5^{* *}\end{array}$ & $\overline{1 \cdot 0-5 \cdot 9}$ & $\begin{array}{l}1 \cdot 0 \\
2 \cdot 0\end{array}$ & $\overline{0} \cdot 65-6 \cdot 3$ \\
\hline HIV* & $\begin{array}{l}-\mathrm{ve} \\
+\mathrm{ve}\end{array}$ & $\begin{array}{r}198 \\
8\end{array}$ & $\begin{array}{l}1.0 \\
0.63\end{array}$ & $\overline{0} \cdot 14-2 \cdot 7$ & $\begin{array}{l}1 \cdot 0 \\
0.57\end{array}$ & $\overline{0} \cdot 12-2 \cdot 8$ \\
\hline Steroids ever used & $\begin{array}{l}\text { No } \\
\text { Yes }\end{array}$ & $\begin{array}{r}123 \\
97\end{array}$ & $\begin{array}{l}1 \cdot 0 \\
1 \cdot 2\end{array}$ & $\overline{0} \cdot 68-2 \cdot 2$ & $\begin{array}{l}1 \cdot 0 \\
1.4\end{array}$ & $\overline{0}-56-3 \cdot 3$ \\
\hline Reversal reaction(s) & $\begin{array}{l}\text { No } \\
\text { Yes }\end{array}$ & $\begin{array}{r}164 \\
56\end{array}$ & $\begin{array}{l}1.0 \\
1.4\end{array}$ & $\overline{0} \cdot 70-2.9$ & $\begin{array}{l}1 \cdot 0 \\
1 \cdot 1\end{array}$ & $\overline{0} \cdot 37-3 \cdot 0$ \\
\hline ENL reaction(s) & $\begin{array}{l}\text { No } \\
\text { Yes }\end{array}$ & $\begin{array}{r}204 \\
16\end{array}$ & $\begin{array}{l}1 \cdot 0 \\
0 \cdot 36\end{array}$ & $\overline{0} \cdot 13-1 \cdot 0$ & $\begin{array}{l}1 \cdot 0 \\
0 \cdot 39\end{array}$ & $\overline{0} \cdot 11-1 \cdot 4$ \\
\hline
\end{tabular}

$* 14 / 220$ patients not tested.

$* *$ Significantly different at $P<0.05$ level.

Our results show that the rate of decline in $\mathrm{BI}$ is independent of most observable clinical features. The rate of decline in log-units per year is not influenced by the initial BI. Early presentation and start of treatment (a delay of less than 3 years) were associated with a faster rate of decline in BI. The rate of decline in the first 2 years after diagnosis is higher than the overall rate, suggesting that the decline follows an exponential curve. It is therefore possible that some patients who present at a late stage in their disease have already passed through a period of rapid decline in $\mathrm{BI}$ and that the observed slower rate after diagnosis reflects their position on the flatter part of the curve. A possibly increased rate of clearance in those with less disability, especially at RFT (an EHF score of less than 3), is not confirmed by the multivariate analysis.

If the decline in $\mathrm{BI}$ is characterized as the time to smear negativity, Table 2 shows that the classification and the initial BI are very important confounding factors. These two factors themselves are of course closely related to each other. It is clear that for the same rate of clearance in terms of log-units per year, patients with a higher initial BI will take longer to reach negativity. This is the likely explanation for the previously quoted findings that $\mathrm{BL}$ 
Table 2. Univariate and multiple logistic regression analysis of risk factors associated with a slow return to smear negativity in 170 Ethiopian leprosy patients

\begin{tabular}{|c|c|c|c|c|c|c|}
\hline Risk factor & Category & $\begin{array}{l}\text { Number } \\
\text { of cases }\end{array}$ & $\begin{array}{l}\text { Univariate } \\
\text { relative risk }\end{array}$ & $95 \% \mathrm{CI}$ & $\begin{array}{l}\text { Adjusted } \\
\text { relative risk }\end{array}$ & $95 \% \mathrm{CI}$ \\
\hline Age group & $\begin{array}{l}<20 \\
20-49 \\
50+\end{array}$ & $\begin{array}{l}49 \\
99 \\
22\end{array}$ & $\begin{array}{l}1 \cdot 0 \\
1 \cdot 2 \\
0.52\end{array}$ & $\begin{array}{l}- \\
0 \cdot 62-2 \cdot 5 \\
0 \cdot 19-1.4\end{array}$ & $\begin{array}{l}1 \cdot 0 \\
2 \cdot 7 \\
0 \cdot 88\end{array}$ & $\begin{array}{l}- \\
0 \cdot 94-7 \cdot 6 \\
0 \cdot 18-4 \cdot 3\end{array}$ \\
\hline Sex & $\begin{array}{l}\text { Male } \\
\text { Female }\end{array}$ & $\begin{array}{r}112 \\
58\end{array}$ & $\begin{array}{l}1 \cdot 0 \\
0.68\end{array}$ & $\overline{0}-36-1 \cdot 3$ & $\begin{array}{l}1 \cdot 0 \\
0.78\end{array}$ & $\overline{0} \cdot 32-1.9$ \\
\hline RJ class & $\begin{array}{l}\text { BL } \\
\text { LL }\end{array}$ & $\begin{array}{r}130 \\
40\end{array}$ & $\begin{array}{l}1 \cdot 0 \\
22 * *\end{array}$ & $\overline{5} \cdot 1-94$ & $\begin{array}{l}1 \cdot 0 \\
5 \cdot 9 * *\end{array}$ & $\overline{1 \cdot 0-33}$ \\
\hline Initial BI & $\begin{array}{l}<4 \\
4,5 \text { or } 6\end{array}$ & $\begin{array}{r}68 \\
102\end{array}$ & $\begin{array}{l}1 \cdot 0 \\
17 * *\end{array}$ & $\overline{6} \cdot 1-44$ & $\begin{array}{l}1 \cdot 0 \\
9 \cdot 3^{* *}\end{array}$ & $\overline{2} \cdot 7-32$ \\
\hline Delay before diagnosis & $\begin{array}{l}\text { Up to } 2 \text { years } \\
3 \text { or more years }\end{array}$ & $\begin{array}{r}115 \\
55\end{array}$ & $\begin{array}{l}1.0 \\
1.0\end{array}$ & $\overline{0}-53-1.9$ & $\begin{array}{l}1 \cdot 0 \\
2 \cdot 4\end{array}$ & $\overline{0} \cdot 81-7 \cdot 1$ \\
\hline EHF at diagnosis & $\begin{array}{l}<3 \\
3 \text { or more }\end{array}$ & $\begin{array}{r}120 \\
50\end{array}$ & $\begin{array}{l}1 \cdot 0 \\
0 \cdot 29 * *\end{array}$ & $\overline{0} \cdot 15-0 \cdot 58$ & $\begin{array}{l}1 \cdot 0 \\
0 \cdot 14 * *\end{array}$ & $\overline{0} \cdot 03-0.64$ \\
\hline EHF at RFT & $\begin{array}{l}<3 \\
3 \text { or more }\end{array}$ & $\begin{array}{r}127 \\
42\end{array}$ & $\begin{array}{l}1 \cdot 0 \\
0 \cdot 50\end{array}$ & $\overline{0} \cdot 25-1 \cdot 0$ & $\begin{array}{l}1 \cdot 0 \\
2 \cdot 3\end{array}$ & $\overline{0} \cdot 52-9 \cdot 7$ \\
\hline HIV* & $\begin{array}{l}-\mathrm{ve} \\
+\mathrm{ve}\end{array}$ & $\begin{array}{r}155 \\
5\end{array}$ & $\begin{array}{l}1 \cdot 0 \\
0 \cdot 16\end{array}$ & $\overline{0} \cdot 01-1 \cdot 5$ & $\begin{array}{l}1 \cdot 0 \\
0 \cdot 11\end{array}$ & $\overline{0} \cdot 07-1 \cdot 5$ \\
\hline Steroids ever used & $\begin{array}{l}\text { No } \\
\text { Yes }\end{array}$ & $\begin{array}{l}86 \\
84\end{array}$ & $\begin{array}{l}1.0 \\
0.63\end{array}$ & $\overline{0} \cdot 34-1 \cdot 2$ & $\begin{array}{l}1 \cdot 0 \\
0.56\end{array}$ & $\overline{0} \cdot 17-1 \cdot 8$ \\
\hline Reversal reaction(s) & $\begin{array}{l}\text { No } \\
\text { Yes }\end{array}$ & $\begin{array}{r}117 \\
53\end{array}$ & $\begin{array}{l}1 \cdot 0 \\
0.53\end{array}$ & $\overline{0} \cdot 27-1 \cdot 0$ & $\begin{array}{l}1 \cdot 0 \\
0 \cdot 84\end{array}$ & $\overline{0} \cdot 24-3 \cdot 0$ \\
\hline ENL reaction(s) & $\begin{array}{l}\text { No } \\
\text { Yes }\end{array}$ & $\begin{array}{r}159 \\
11\end{array}$ & $\begin{array}{l}1.0 \\
8.0\end{array}$ & $\overline{1} \cdot 0-64$ & $\begin{array}{l}1 \cdot 0 \\
5 \cdot 3\end{array}$ & $\overline{0} \cdot 38-75$ \\
\hline
\end{tabular}

$* 11 / 170$ patients not tested.

** Significantly different at $P<0.05$ level.

patients and those with reversal reactions reach smear negativity more quickly, while LL patients and those with ENL reactions do so more slowly. In the univariate analysis, the effect of reversal reactions in speeding clearance, and the effect of ENL in retarding clearance, just reach statistical significance, but these findings do not persist in the multivariate analysis, suggesting that they may be largely explained by the classification and initial BI. More severe impairment at the start of treatment was significantly related to a faster return to negativity and the multivariate analysis shows that this cannot be fully explained by the classification and initial BI.

In conclusion, it is suggested that the rate of decline in $\mathrm{BI}$ in log-units per year is a more appropriate method of assessing the removal of bacilli than the time to smear negativity, which is largely a reflection of the classification and initial BI. Our results show that a delay of less than 3 years between initial symptoms of leprosy and the start of treatment leads to significantly faster clearance of bacilli from the body. The relationship between impairment and the clearance of bacilli is obscure, although there is clearly no association between the occurrence of reversal reactions and the decline in BI. 


\section{Acknowledgements}

We thank the staff of the ALERT Leprosy/TB Control Division for their dedication and perseverance in managing the patients and collecting data over so many years and Professor Morten Harboe for helpful comments on the manuscript. The financial support of ILEP, through Netherlands Leprosy Relief (NLR), has been constant throughout the 12 years of the study and is gratefully acknowledged. We also thank ALERT as a whole for institutional and administrative support.

\section{References}

${ }^{1}$ WHO Leprosy Unit. Risk of relapse in leprosy. WHO document, WHO/CTD/LEP/94.1, 1994.

2 Ji B. Why multidrug therapy for multibacillary leprosy can be shortened to 12 months. Lepr Rev, 1998; 69: 106109.

${ }^{3}$ Waters MF. Is it safe to shorten multidrug therapy for lepromatous (LL and BL) leprosy to 12 months? Lepr Rev, 1998; 69: 110-111.

${ }^{4}$ Lynch P. Multidrug therapy. Lepr Rev, 1999; 70: 70-71.

${ }_{6}^{5}$ van Brakel WH. Proposal regarding MB MDT. Lepr Rev, 1999; 70: 71-73.

6 Anonymous. Response to treatment by multidrug regimens in the THELEP controlled clinical drug trials. Subcommittee on Clinical Trials of the Chemotherapy of Leprosy (THELEP) Scientific Working Group of the UNDP/World Bank/WHO Special Programme for Research and Training in Tropical Diseases. Lepr Rev, 1996; 67: 260-279.

7 Pattyn SR, Groenen G, Janssens L et al. Combined regimens of one year duration in the treatment of multibacillary leprosy - II. Combined regimens with rifampicin administered during 6 months. Lepr Rev, 1989; 60: 118-123.

8 Jesudasan K, Vijayakumaran P, Manimozhi N et al. Effectiveness of MDT in multibacillary leprosy. Int J Lepr, 1996; 64: 128-132.

9 de Carsalade G, Wallach D, Spindler E et al. Daily multidrug therapy for leprosy; results of a fourteen year experience. Int J Lepr, 1997; 65: 37-44.

10 Meima A, Saunderson PR, Gebre S et al. Factors associated with impairments in new leprosy patients: the AMFES cohort. Lepr Rev, 1999; 70: 189-203. 